\title{
Maternal intake of fatty acids during pregnancy and allergies in the offspring
}

\author{
Bright I. Nwaru ${ }^{1 *}$, Maijaliisa Erkkola ${ }^{2}$, Mirka Lumia ${ }^{3}$, Carina Kronberg-Kippilä ${ }^{3}$, Suvi Ahonen ${ }^{1,4}$, \\ Minna Kaila ${ }^{5}$, Jorma Ilonen ${ }^{6,7}$, Olli Simell ${ }^{8}$, Mikael Knip ${ }^{5,9,10}$, Riitta Veijola ${ }^{11}$ and Suvi M. Virtanen ${ }^{1,3,4,5}$ \\ ${ }^{1}$ School of Health Sciences, University of Tampere, Tampere FIN-33014, Finland \\ ${ }^{2}$ Department of Food and Environmental Sciences, Division of Nutrition, University of Helsinki, Helsinki, Finland \\ ${ }^{3}$ Nutrition Unit, Department of Lifestyle and Participation, National Institute of Health and Welfare, Helsinki, Finland \\ ${ }^{4}$ The Science Center of Pirkanmaa Hospital District, Tampere, Finland \\ ${ }^{5}$ Department of Pediatrics, Tampere University Hospital, Tampere, Finland \\ ${ }^{6}$ Immunogenetics Laboratory, University of Turku, Turku, Finland \\ ${ }^{7}$ Department of Clinical Microbiology, University of Eastern Finland, Kuopio, Finland \\ ${ }^{8}$ Department of Pediatrics, University of Turku, Turku, Finland \\ ${ }^{9}$ Children's Hospital, University of Helsinki, Helsinki University Central Hospital, Helsinki, Finland \\ ${ }^{10}$ Folkhälsan Research Center, Helsinki, Finland \\ ${ }^{11}$ Department of Pediatrics, University of Oulu, Oulu, Finland
}

(Submitted 15 April 2011 - Final revision received 4 October 2011 - Accepted 5 October 2011 - First published online 9 November 2011)

\begin{abstract}
Fatty acids (FA) are known to have a number of immunological effects and, accordingly, may play a role in the development of allergic diseases. We investigated the effect of maternal intake of FA during pregnancy on the risk of allergic rhinitis, wheeze and atopic eczema in children aged 5 years. The present study analysed data from the Finnish Type 1 Diabetes Prediction and Prevention Nutrition Study, a population-based birth cohort study with a 5-year follow-up. Complete information on maternal diet (assessed by a validated FFQ) and International Study of Asthma and Allergies in Childhood-based allergic outcomes was available for 2441 children. Cox proportional regression and logistic regression were used for the analyses. After adjusting for potential confounding variables, high maternal consumption of butter and butter spreads (hazard ratio (HR) 1.33 ; $95 \%$ CI $1 \cdot 03,1 \cdot 71$ ) and higher ratio of $n$-6: $n$ - 3 FA (HR $1 \cdot 37 ; 95 \%$ CI $1 \cdot 07,1 \cdot 77$ ) during pregnancy were associated with an increased risk of allergic rhinitis in the offspring by 5 years of age. High maternal intakes of total PUFA (HR 0.71; $95 \%$ CI 0.52, 0.96) and $\alpha$-linolenic FA (HR 0.73; $95 \%$ CI 0.54, 0.98) were associated with a decreased risk of allergic rhinitis. However, these results lost their significance after adjustment for multiple comparisons. Overall, our data suggest that maternal consumption of butter, the ratio of $n-6: n-3$ FA and intake of PUFA and $\alpha$-linolenic FA during pregnancy may be potential determinants of allergic rhinitis in the offspring.
\end{abstract}

Key words: Allergic rhinitis: Atopic eczema: Children: Fatty acids: Maternal diet: Pregnancy: Wheeze

The increasing prevalence of allergic diseases in Western countries has partly been linked to changes in the modern $\operatorname{diet}^{(1)}$, particularly changes in the intake of dietary fats ${ }^{(2)}$. Over the past few decades, consumption of foods rich in $n$-6 PUFA has increased, whereas that of $n-3$ PUFA has decreased. Arachidonic acid (AA), which is an n-6 PUFA, is a precursor for pro-inflammatory eicosanoids, while $n$-3 EPA, is a precursor for anti-inflammatory eicosanoids ${ }^{(3)}$. Changes in fatty acid consumption may shift the T-helper balance from type 1 to type 2 , which, consequently, may increase the incidence of IgE-mediated allergic diseases ${ }^{(3,4)}$.
The results of studies on the association between dietary intake of fats and fatty acids (FA) during pregnancy and allergic diseases in the offspring are inconsistent. A recent Japanese cohort study has linked maternal intake of $\alpha$-linolenic acid and DHA during pregnancy to a reduced risk of wheezing in 2-year-old children, while intake of $n-6$ PUFA and linoleic acid was associated with an increased risk of eczema ${ }^{(5)}$. Maternal consumption of butter and margarine was not associated with atopy in the offspring in an Italian cohort study $^{(6)}$. Maternal fish consumption decreased the risk of allergic diseases in the offspring ${ }^{(6-10)}$. In contrast, maternal

Abbreviations: AA, arachidonic acid; DIPP, Diabetes Prediction and Prevention; FA, fatty acids.

*Corresponding author: B. I. Nwaru, fax +358 401901665, email bright.nwaru@uta.fi 
fish consumption was not associated with asthma or asthma symptoms in the offspring in a Dutch follow-up study ${ }^{(11)}$. Further research is required in this area to elucidate the putative role of dietary fats during pregnancy and early life in the development of allergies. In the present large cohort with a relatively long follow-up, we aimed at examining the effects of maternal intake of dietary fats and a wide range of FA during pregnancy on the development of allergic rhinitis, wheeze and atopic eczema in the offspring by the age of 5 years.

\section{Materials and methods}

\section{Subjects}

In 1994, the Finnish Type 1 Diabetes Prediction and Prevention (DIPP) study was started. It is a multidisciplinary population-based prospective cohort study that examines potential means to predict and prevent type 1 diabetes $^{(12)}$. Newborn infants with human leucocyte antigen (HLA)conferred susceptibility to type 1 diabetes are recruited from three university hospitals in Finland (Turku, Oulu and Tampere) and monitored at 3-12-month intervals for diabetes-associated antibodies, growth and environmental exposures. The present study was conducted according to the guidelines laid down in the Declaration of Helsinki and all procedures involving human subjects were approved by the ethics committees of the Universities of Oulu and Tampere. Written informed consent was obtained from the parents.

In September 1996 and October 1997, the DIPP Nutrition Study was started within the framework of the DIPP study in Oulu (Northern Finland) and Tampere (Southern Finland), respectively ${ }^{(13)}$, examining the relationship of maternal diet during pregnancy and lactation, and the child's diet during infancy to the development of type 1 diabetes, allergic diseases and asthma in childhood. At the age of 5 years, 3523 children who were still participating in the dietary follow-up (born between 20 October 1997 and 29 February 2004) were invited to take part in the allergy study by completing a questionnaire on the child's history of allergic symptoms. Altogether 3253 ( $92 \%$ of those invited) participated in the allergy study. Of these, complete information on maternal diet during pregnancy was available for 2441 children $(75 \%$ of those who participated in the allergy study).

\section{Dietary assessment}

Maternal food consumption during the last month before the beginning of maternity leave, i.e. the 8th month of pregnancy, was assessed using a validated 181-item $\mathrm{FFQ}^{(14)}$. The FFQ specially reflected the diet of Finnish women of childbearing age. Mothers received the FFQ after delivery and recorded the foods they had eaten during the month preceding their pregnancy leave. The use of supplements during the whole pregnancy period was also recorded. The FFQ was returned to the study centre at the child's 3-month visit and was checked by a study nurse. Software of the National Institute for Health and Welfare, Helsinki, Finland, was used to convert the food consumption data to daily nutrient intake, taking into account women's individual choices of fats used in food preparations and baking, and oils used for salad dressing ${ }^{(15)}$. The dietary exposures investigated in the present study include the main dietary fats (butter, margarine and oils) and a range of FA (SFA, MUFA, PUFA and their subsidiaries). In the validation of the FFQ against a $10 \mathrm{~d}$ food records, the energy-adjusted and attenuationcorrected correlation coefficients for these dietary exposures were as follows: total fat (0.48), butter (0.77), margarines (0.64) and oils (0.22), SFA (0.55), MUFA (0.34), PUFA (0.47), $n-3$ PUFA (0.39) and $n-6$ PUFA (0.49). Overall, $70 \%$ of the foods and $69 \%$ of the nutrients fell into the same or adjacent quintiles ${ }^{(14)}$.

\section{Assessment of allergic outcomes}

At the age of 5 years, families of the participating children completed a questionnaire modified from the International Study of Asthma and Allergies in Childhood questionnaire on the child's history of allergic symptoms ${ }^{(16,17)}$. Allergic rhinitis was defined as sneezing, nasal congestion or rhinitis other than with respiratory infections, accompanied by itching of the eye and tearing during the previous 12 months. Wheezing was defined as parental 'yes' answer on whether the child has had any of the following during the past 12 months: wheezy sound in respiration; wheezy sound in respiration in connection with physical activity; difficulties in respiration in the morning on waking up; wheezy respiration without having the sniffles or respiratory infection; dry cough at nights not associated with common colds or respiratory infections. Age of the onset of rhinitis and wheeze was indicated by the date of the doctor-made diagnosis. Atopic eczema was defined with a positive answer to the question: 'Has your child ever had atopic eczema?'

\section{Sociodemographic and perinatal characteristics}

Information on the child's sex, maternal age, maternal educational level and the number of siblings was recorded in a structured questionnaire completed by the parents after the delivery. Information on duration of gestation, birth weight and height, and maternal smoking during pregnancy was received from the Medical Birth Registries of Oulu and Tampere University Hospitals.

\section{Statistical analysis}

The distribution of maternal intake of $n-3$ and $n-6$ PUFA in the study population was analysed using the $t$ test and ANOVA. Cox proportional hazards regression was used to estimate the risk of the onset of allergic rhinitis and wheeze (because we had the follow-up times for these outcomes), while logistic regression was used to estimate the prevalence of atopic eczema. The FA were energy adjusted by the residual method ${ }^{(18)}$ while total energy intake was included in the models containing the dietary fats. The dietary

\footnotetext{
3-month visit and was checked by a study nurse. Software
} 
variables were categorised in quarters, and the two middle quarters were combined and used as the reference category. A priori, we judge that the two middle quarters constitute those with average diet intake in the study population, thus using them as the reference category and comparing the other two extreme quarters seems logical. Selection of confounding covariates was based on their relationships with the exposure and/or the outcome and, in respect of nutrients, on earlier findings. In the adjusted models, the following covariates were included and categorised as shown in Table 1: sex of child, hospital of birth, duration of gestation, maternal age at delivery, maternal basic education, maternal smoking during pregnancy, mode of delivery, number of siblings at the time of the child's birth, parental asthma, parental allergic rhinitis, pets at home by 1 year of age. A second adjusted model was computed for the FA in which potentially confounding nutrients, vitamin $\mathrm{C}, \mathrm{Zn}$, Se, vitamin $\mathrm{D}$ and vitamin $\mathrm{E}$ were included as additional covariates. Correction for multiple comparisons was performed using the Bonferroni adjustments. All analyses were computed using SPSS version 15.0 (SPSS, Inc., IL, USA).

\section{Results}

Participants in the allergy study were generally not systematically different from non-participants regarding the

Table 1. Distribution of maternal intake of $n-3$ and $n-6$ PUFA by the characteristics of the participating children (Mean values with their standard errors, $n$ 2441)

\begin{tabular}{|c|c|c|c|c|c|c|}
\hline \multirow[b]{2}{*}{ Characteristics } & \multicolumn{3}{|c|}{ Maternal intake of $n-3$ PUFA } & \multicolumn{3}{|c|}{ Maternal intake of $n-6$ PUFA } \\
\hline & Mean $(g / d)$ & SD & $P^{*}$ & Mean $(g / d)$ & SD & $P^{*}$ \\
\hline Sex & & & 0.752 & & & 0.186 \\
\hline Boys & $3 \cdot 2$ & 1.2 & & $10 \cdot 7$ & 3.7 & \\
\hline Girls & $3 \cdot 2$ & 1.3 & & 10.9 & $4 \cdot 3$ & \\
\hline Delivery hospital & & & 0.129 & & & 0.013 \\
\hline Oulu (Northern Finland) & $3 \cdot 1$ & 1.3 & & 10.5 & 3.8 & \\
\hline Tampere (Southern Finland) & 3.2 & $1 \cdot 7$ & & $10 \cdot 9$ & 4.2 & \\
\hline Duration of gestation & & & 0.634 & & & 0.139 \\
\hline Quarter: $\leq 38.90$ weeks & $3 \cdot 1$ & 1.2 & & 10.5 & 3.7 & \\
\hline Quarter: $39.00-39.90$ weeks & $3 \cdot 2$ & 1.2 & & $10 \cdot 8$ & 3.8 & \\
\hline Quarter: $40 \cdot 00-40.70$ weeks & $3 \cdot 2$ & 1.2 & & $10 \cdot 9$ & 4.0 & \\
\hline Quarter: $>40 \cdot 70$ weeks & $3 \cdot 2$ & $1 \cdot 3$ & & $11 \cdot 0$ & 4.5 & \\
\hline Missing & & & & & & \\
\hline Maternal age & & & $<0.001$ & & & 0.355 \\
\hline$<25$ years & 3.0 & $1 \cdot 2$ & & $10 \cdot 6$ & $4 \cdot 1$ & \\
\hline $25-29$ years & $3 \cdot 1$ & 1.2 & & $10 \cdot 7$ & 4.2 & \\
\hline $30-34$ years & $3 \cdot 2$ & 1.3 & & $10 \cdot 8$ & 3.9 & \\
\hline$\geq 35$ years & $3 \cdot 3$ & 1.3 & & $11 \cdot 0$ & 3.8 & \\
\hline Maternal basic education & & & $<0.001$ & & & 0.016 \\
\hline Less than high school & $3 \cdot 0$ & 1.3 & & 10.5 & 4.2 & \\
\hline High school graduate & $3 \cdot 2$ & 1.3 & & $10 \cdot 9$ & 3.9 & \\
\hline Maternal smoking during pregnancy & & & 0.947 & & & 0.015 \\
\hline No & $3 \cdot 2$ & 1.3 & & $10 \cdot 7$ & 3.8 & \\
\hline Yes & $3 \cdot 1$ & $1 \cdot 2$ & & $12 \cdot 5$ & $7 \cdot 1$ & \\
\hline No information & $3 \cdot 2$ & 1.4 & & $11 \cdot 3$ & $5 \cdot 2$ & \\
\hline Mode of delivery & & & 0.923 & & & 0.888 \\
\hline Vaginal delivery & 3.2 & $1 \cdot 2$ & & $10 \cdot 8$ & 4.0 & \\
\hline Forceps or suction & $3 \cdot 2$ & $1 \cdot 2$ & & $10 \cdot 8$ & 3.5 & \\
\hline Caesarean section & $3 \cdot 1$ & 1.4 & & $10 \cdot 9$ & 4.5 & \\
\hline Number of siblings & & & 0.006 & & & 0.020 \\
\hline None & $3 \cdot 1$ & 1.2 & & $10 \cdot 5$ & 3.8 & \\
\hline One & 3.3 & 1.3 & & $11 \cdot 1$ & 4.1 & \\
\hline Two or more & $3 \cdot 2$ & $1 \cdot 3$ & & $10 \cdot 9$ & 4.4 & \\
\hline Parental asthma & & & 0.039 & & & 0.136 \\
\hline No & $3 \cdot 2$ & 1.3 & & $10 \cdot 8$ & 4.0 & \\
\hline Yes & $3 \cdot 1$ & $1 \cdot 3$ & & $10 \cdot 6$ & 4.1 & \\
\hline No information & $2 \cdot 7$ & 1.0 & & 9.5 & 3.5 & \\
\hline Parental allergic rhinitis & & & 0.194 & & & 0.386 \\
\hline No & $3 \cdot 2$ & 1.3 & & $10 \cdot 8$ & 4.1 & \\
\hline Yes & $3 \cdot 1$ & $1 \cdot 3$ & & $10 \cdot 8$ & 3.9 & \\
\hline No information & $3 \cdot 4$ & 1.3 & & $11 \cdot 3$ & 4.8 & \\
\hline Atopic eczema by 6 months of age & & & 0.318 & & & 0.656 \\
\hline No & $3 \cdot 2$ & $1 \cdot 3$ & & $10 \cdot 8$ & 4.1 & \\
\hline Yes & $3 \cdot 2$ & 1.2 & & $10 \cdot 7$ & 3.9 & \\
\hline Pets at home during the first year & & & 0.587 & & & 0.090 \\
\hline No & $3 \cdot 2$ & 1.3 & & $10 \cdot 7$ & 3.9 & \\
\hline Yes & $3 \cdot 2$ & 1.3 & & $11 \cdot 0$ & 4.3 & \\
\hline
\end{tabular}

* Based on the $t$ test or ANOVA. 
background characteristics of the study population either in absolute or relative terms, except for the place of birth: those from Southern Finland were slightly more likely not to take part in the study (10\%) than those from Northern Finland (4\%; $P<0.001)$. The mean total daily intake of energy for participating mothers was 11386 (SD 3148)kJ. Protein accounted for $16 \%$ (mean intake $110 \mathrm{~g}$; SD 31), fat for $35 \%$ (105 g; SD 34) and total carbohydrates for 49\% (325 g; SD 95) of the total energy intake. The mean total daily intake of SFA was 45 (SD 17) g, MUFA 37 (SD 12) g, $n$-3 PUFA $3 \cdot 2$ (SD 1.3) g and $n$-6 PUFA $10 \cdot 8$ (SD $4 \cdot 0) \mathrm{g}$. None of the women was taking fatty acid supplements during pregnancy.

Significantly higher mean daily intake of $n$-3 PUFA was seen among women over 35 years of age, women with high school degree, children with one sibling and children without parental asthma (Table 1). A higher intake of $n-6$ PUFA was seen among those from Southern Finland, women with high school degree, women who smoked during pregnancy and among children with one sibling. Duration of gestation for more than 40 weeks and having a pet at home during the first year of the child were associated with a decreased risk of atopic eczema, whereas children with parental asthma and rhinitis were at increased risk of atopic eczema. A decreased risk of allergic rhinitis was seen among girls, while children with parental asthma, those with parental rhinitis and those who had atopic eczema by 6 months of age appeared to have an increased risk of rhinitis. Increasing maternal age was associated with decreased risk, whereas increasing number of siblings increased the risk of wheeze (Table 2).

After adjusting for potential confounders, none of the dietary fats or FA was significantly associated with atopic eczema and wheeze. For allergic rhinitis, high maternal consumption of butter and butter spreads was associated with an increased risk of the emergence of allergic rhinitis in the offspring by the age of 5 years (Table 3). A higher ratio of $n-6: n-3$ FA during pregnancy was associated with an increased risk of allergic rhinitis (Table 4). On the other hand, a decreased risk of allergic rhinitis was observed with high intakes of total PUFA and $\alpha$-linolenic FA (Table 4). These results did not change in the models adjusted additionally for the effect of vitamin $\mathrm{C}, \mathrm{Zn}, \mathrm{Se}$, vitamin $\mathrm{D}$ and vitamin $\mathrm{E}$ (Table 5). However, after a Bonferroni correction for multiple comparisons, these results lost their statistical significance.

\section{Discussion}

The results from the present study show that high maternal consumption of butter and higher ratio of $n-6: n-3$ FA during pregnancy were associated with an increased risk of allergic rhinitis in the offspring by the age of 5 years. Conversely, high maternal intake of total PUFA and $\alpha$-linolenic FA was associated with a decreased risk of rhinitis in the offspring. Adjustment for the effects of vitamin C, Zn, Se, vitamin D and vitamin $\mathrm{E}$ did not alter these results, but the results were no longer significant after correction for multiple comparisons.
As a prospective study, the determination of dietary intake before the emergence of the outcomes ensured minimising bias related to the selection of the subjects. The FFQ used in the present study was validated and is suitable for the assessment of dietary intake among childbearing Finnish women ${ }^{(14)}$. The rationale for the dietary assessment was to get a general picture of the diet of the mothers during the first 8 months of pregnancy. We assumed that by assessing the maternal diet during the month preceding the maternity leave (i.e. the 8th month of pregnancy), we obtained a more appropriate overall picture of the maternal diet during pregnancy than by assessing it over the period of the last month before delivery (the 9th month) when most of the mothers did not work outside the home any longer. Dietary measurement error is most consequential if a proportion of subjects are misclassified according to the exposure. There are three recommended validity estimates for nutrients of interest in epidemiological studies: Spearman's correlation coefficients should be above $0 \cdot 5$; more than $50 \%$ of subjects should be correctly classified; less than $10 \%$ of subjects should be grossly misclassified into thirds ${ }^{(19)}$. In terms of dietary fats, the greatest misclassifications were found for MUFA ( $9 \%$ of the subjects grossly misclassified). Although biomarker assessments represent a precise estimate of the FA, they are limited by being unable to assess the long-term nutrient status. In this case, the FFQ is beneficial, since long-term and habitual intake can be measured. By assessing maternal dietary intake during the 8th month of pregnancy, we aimed at estimating the overall picture of maternal diet during the first 8 months of pregnancy. Although some seasonal variations have been observed in maternal diet during pregnancy as a result of fluctuations in nutrient intakes ${ }^{(20)}$, it has been suggested that such changes may be difficult to accurately detect with the rather imprecise dietary assessment methods currently available ${ }^{(21)}$. Consequently, our generalisation of maternal dietary intake during the 8th month to the whole pregnancy period may remain only a rough approximation. In order to improve the classification of dietary fats, the grouping and brand names of spreads in our FFQ are continuously checked and updated. Most importantly, the overall quintile notation was acceptable for all FA.

There is considerable heterogeneity in respiratory symptoms among children. Consequently, we found associations between FA and rhinitis but not with eczema and wheeze. We lack the knowledge on the mechanisms and the optimal timing of exposure to lower or higher FA levels to influence the development of the different allergic diseases. To exclude younger children having transient respiratory symptoms related to viral infections, the endpoints in the present study were measured in subjects aged 5 years. Because of the lack of data, the child's fat and/or fatty acid intake was not included into our models as a possible confounding factor; thus, we cannot totally rule out that the present results might not have been influenced by dietary intake during infancy. Previous findings have suggested that processes leading to allergic diseases can be initiated very early in the immune development ${ }^{(22,23)}$. The complex relationship between early nutrition and allergic outcomes emphasises 
Table 2. Relationship of characteristics of the participating children $(n$ 2441) to the incidence of atopic eczema, allergic rhinitis and wheeze by 5 years of age

(Number of participants, percentages, odds ratios, hazard ratios and $95 \%$ confidence intervals)

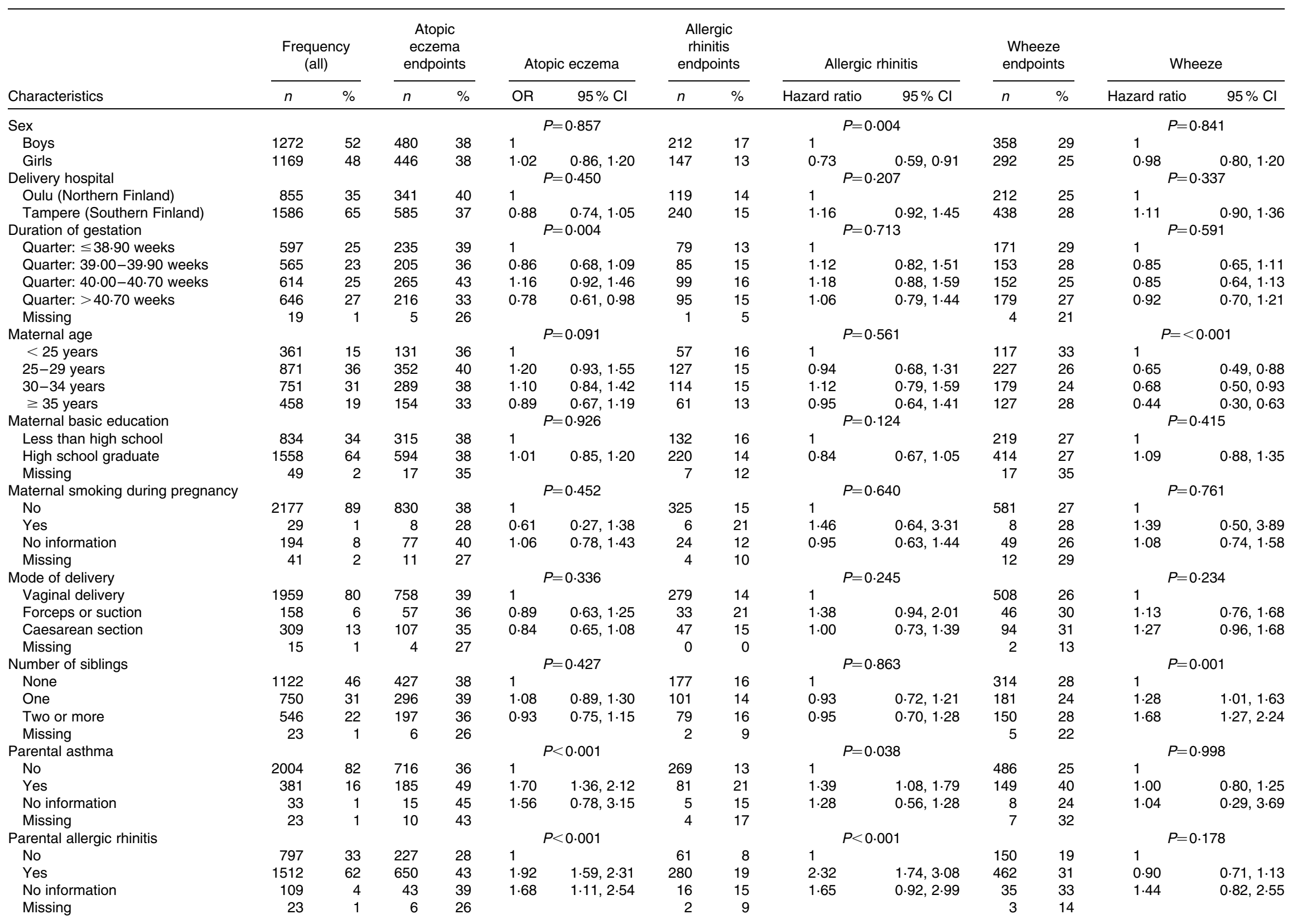




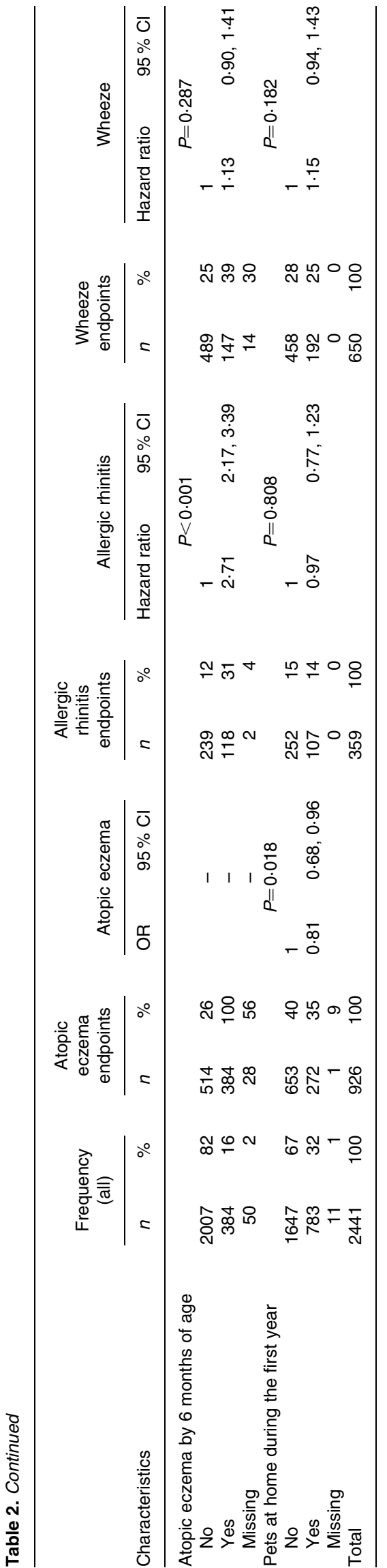

the need for consistent and thorough assessment of maternal diets throughout the duration of pregnancy and the child's diet throughout early years. However, duration of exclusive and total breast-feeding has not been related to allergic outcomes in our cohort.

After adjusting for multiple comparisons, the results no longer achieved statistical significance. Therefore, we suggest caution in the interpretation of the present findings. However, we note that the hypotheses linking each of the FA and allergies are mixed, and the precise mechanisms of the role of fatty acids on the occurrence of allergies are not clearly elucidated. Consequently, we believe that each of the associations between the studied FA and the allergic outcomes should be judged on its own merit. Furthermore, the limited and conflicting reports in this area of research signify that reproducibility of these results in further studies would be crucial to rule out any chance finding.

The genetic susceptibility to type 1 diabetes of our study subjects may constrain the generalisability of the present results. Type 1 diabetes is associated with $\mathrm{T}$ helper cell 1 (Th1) immune responses, while allergic diseases are related to $\mathrm{T}$ helper cell 2 (Th2)-type responses ${ }^{(24)}$. In addition to the complexities surrounding the components of the immune system that relate to the generation of Th1 and Th2 responses, it is inconclusive how type 1 diabetes and allergies may be associated $^{(25)}$. However, the cumulative incidence of allergies in the present study paralleled that observed in the general Finnish population $^{(17,26)}$. Furthermore, our subjects were unselected in terms of history of allergy, thus minimising bias towards more selection of children with a positive history for allergic diseases. Participants in the present allergy study were generally not systematically different from nonparticipating women regarding the background characteristics, suggesting that differential loss to follow-up was minimised in the present study.

The immunological properties of FA have been elaborated $^{(3,27)}$, particularly that of the $n-3$ and $n-6$ families, which represent the most widely studied FA. While $n-6$ PUFA may possess pro-inflammatory properties, n-3 PUFA are thought to act as anti-inflammatory mediators ${ }^{(27,28)}$. These effects may be prominent during fetal and early life, emphasising the consequences of maternal intake of FA during pregnancy ${ }^{(29,30)}$. In the present study, while both $n-6$ and $n$-3 PUFA were not appreciably related to the outcomes, total PUFA and $\alpha$-linolenic FA, however, were associated with a decreased risk of rhinitis. In addition to our present findings, our earlier report has shown an unclear association between maternal intake of PUFA during pregnancy and allergen-specific IgE sensitisation in the offspring in a different subject series of this cohort ${ }^{(31)}$. In a Japanese study, maternal intake of $\alpha$-linolenic acid during pregnancy was associated with a reduced risk of wheezing in 2-year-old children ${ }^{(5)}$. Also, consistent with the present findings, no association was seen between any of the FA and suspected eczema in the Japanese children at the age of 3-4 months ${ }^{(32)}$. The younger age of children in the Japanese cohort makes it likely that their wheezing symptoms may be a result of viral infections, which are usually unrelated to 
Table 3. Association between maternal consumption of dietary fats during pregnancy and prevalence of atopic eczema and incidence of allergic rhinitis and wheeze in 5-year-old children (Hazard ratios (HR), odds ratios and $95 \%$ confidence intervals)

\begin{tabular}{|c|c|c|c|c|c|c|c|c|c|c|c|c|}
\hline \multirow[b]{3}{*}{ Food variables } & \multicolumn{4}{|c|}{ Atopi eczema } & \multicolumn{4}{|c|}{ Allergic rhinitis } & \multicolumn{4}{|c|}{ Wheeze } \\
\hline & \multicolumn{2}{|c|}{ Unadjusted $\dagger$} & \multicolumn{2}{|c|}{ Adjusted $\neq$} & \multicolumn{2}{|c|}{ Unadjusted $\dagger$} & \multicolumn{2}{|c|}{ Adjusted $\ddagger$} & \multicolumn{2}{|c|}{ Unadjusted $\dagger$} & \multicolumn{2}{|c|}{ Adjustedł } \\
\hline & HR & $95 \% \mathrm{Cl}$ & $\mathrm{HR}$ & $95 \% \mathrm{Cl}$ & OR & $95 \% \mathrm{Cl}$ & OR & $95 \% \mathrm{Cl}$ & $\mathrm{HR}$ & $95 \% \mathrm{Cl}$ & $\mathrm{HR}$ & $95 \% \mathrm{Cl}$ \\
\hline \multicolumn{13}{|l|}{ Butter and butter spreads } \\
\hline First quarter $(<4.72 \mathrm{~g} / \mathrm{d})$ & 0.91 & $0.74,1.11$ & 0.94 & $0.76,1.17$ & $1 \cdot 10$ & $0.85,1.43$ & 1.07 & $0.81,1.42$ & 1.07 & $0.84,1.35$ & 1.09 & $0.84,1.41$ \\
\hline Second and third quarters $(4.7-19.82 \mathrm{~g} / \mathrm{d})$ & 1 & & 1 & & 1 & & 1 & & 1 & & 1 & \\
\hline Fourth quarter $(19.83-128.38 \mathrm{~g} / \mathrm{d})$ & 1.09 & $0.89,1.34$ & 1.05 & $0.85,1.30$ & $1.42^{*}$ & $1.11,1.81$ & $1.33^{*}$ & $1.03,1.71$ & 0.84 & $0.67,1.06$ & 0.80 & $0.62,1.03$ \\
\hline \multicolumn{13}{|l|}{ Industrial fats§ } \\
\hline First quarter $(<4.84 \mathrm{~g} / \mathrm{d})$ & 0.96 & $0.78,1 \cdot 17$ & 0.94 & $0.76,1.17$ & 0.81 & $0.62,1.05$ & 0.76 & $0.58,1.00$ & 1.02 & $0.81,1.29$ & 0.95 & $0.74,1.23$ \\
\hline Second and third quarters $(4.85-10.85 \mathrm{~g} / \mathrm{d})$ & 1 & & 1 & & 1 & & 1 & & 1 & & 1 & \\
\hline Fourth quarter $(10.86-115.93 \mathrm{~g} / \mathrm{d})$ & 0.94 & $0.75,1.17$ & 0.95 & $0.76,1.20$ & 0.91 & $0.69,1.20$ & 0.89 & $0.67,1.18$ & 1.21 & $0.94,1.56$ & $1 \cdot 16$ & $0.89,1.52$ \\
\hline \multicolumn{13}{|l|}{ Margarines } \\
\hline Non-consumers & 1 & & 1 & & 1 & & 1 & & 1 & & 1 & \\
\hline Consumers $(0.06-120 \mathrm{~g} / \mathrm{d})$ & 0.92 & $0.78,1.09$ & 0.92 & $0.77,1.09$ & 0.88 & $0.72,1.09$ & 0.89 & $0.72,1 \cdot 11$ & 1.03 & $0.85,1.26$ & 1.04 & $0.84,1.29$ \\
\hline \multicolumn{13}{|l|}{ Oils } \\
\hline First quarter $(<7.25 \mathrm{~g} / \mathrm{d})$ & 0.98 & $0.80,1.20$ & 0.91 & $0.73,1.13$ & 0.92 & $0.71,1 \cdot 19$ & 0.86 & $0.66,1.12$ & 0.87 & $0.68,1 \cdot 10$ & 0.88 & $0.68,1.14$ \\
\hline Second and third quarters $(7.25-16.37 \mathrm{~g} / \mathrm{d})$ & 1 & & 1 & & 1 & & 1 & & 1 & & 1 & \\
\hline Fourth quarter $(16.38-145.00 \mathrm{~g} / \mathrm{d})$ & 0.97 & $0.80,1.19$ & 1.01 & $0.81,1.26$ & 0.79 & $0.61,1.03$ & 0.81 & $0.61,1.07$ & 0.98 & $0.78,1.24$ & 1.05 & $0.82,1.35$ \\
\hline
\end{tabular}

Total energy included in the model.

¥Adjusted for total energy, sex of child, hospital of birth, duration of gestation, maternal age at delivery, maternal basic education, maternal smoking during pregnancy, mode of delivery, number of siblings at the time of the child's

$\S$ Industrial fats: industrial fat mixes and animal fats (grease, suet, lard). 
Table 4. Association between maternal fatty acid intake during pregnancy and prevalence of atopic eczema and incidence of allergic rhinitis and wheeze in 5-year-old children (Hazard ratios (HR), odds ratios and $95 \%$ confidence intervals)

\begin{tabular}{|c|c|c|c|c|c|c|c|c|c|c|c|c|}
\hline \multirow[b]{3}{*}{ Fatty acids } & \multicolumn{4}{|c|}{ Atopic eczema } & \multicolumn{4}{|c|}{ Allergic rhinitis } & \multicolumn{4}{|c|}{ Wheeze } \\
\hline & \multicolumn{2}{|c|}{ Unadjusted } & \multicolumn{2}{|c|}{ Adjusted model I† } & \multicolumn{2}{|c|}{ Unadjusted } & \multicolumn{2}{|c|}{ Adjusted model I† } & \multicolumn{2}{|c|}{ Unadjusted } & \multicolumn{2}{|c|}{ Adjusted model I† } \\
\hline & OR & $95 \% \mathrm{Cl}$ & OR & $95 \% \mathrm{Cl}$ & $\mathrm{HR}$ & $95 \% \mathrm{Cl}$ & HR & $95 \% \mathrm{Cl}$ & $\mathrm{HR}$ & $95 \% \mathrm{Cl}$ & $\mathrm{HR}$ & $95 \% \mathrm{Cl}$ \\
\hline \multicolumn{13}{|l|}{ Total fatty acids } \\
\hline First quarter $(<196.85 \mathrm{~g} / \mathrm{d})$ & 0.89 & $0.72,1.09$ & 0.84 & $0.68,1.04$ & 0.93 & $0.71,1 \cdot 20$ & 0.92 & $0.70,1.20$ & 1.02 & $0.80,1.28$ & 1.03 & $0.81,1.33$ \\
\hline Second and third quarters $(196.85-280.83 \mathrm{~g} / \mathrm{d})$ & 1 & & 1 & & 1 & & & & 1 & & 1 & \\
\hline Fourth quarter $(280.84-299.25 \mathrm{~g} / \mathrm{d})$ & 1.03 & $0.85,1.26$ & 1.04 & $0.84,1.28$ & 0.96 & $0.75,1.24$ & 0.98 & $0.75,1.27$ & 0.99 & $0.79,1.25$ & 0.95 & $0.74,1.21$ \\
\hline \multicolumn{13}{|l|}{ SFA } \\
\hline First quarter $(<82 \cdot 24 \mathrm{~g} / \mathrm{d})$ & 1.01 & $0.83,1 \cdot 24$ & 0.99 & $0.80,1.23$ & 1.07 & $0.83,1.38$ & 1.06 & $0.82,1.39$ & 1.00 & $0.80,1.26$ & 0.99 & $0.79,1.27$ \\
\hline Second and third quarters $(82.24-118.56 \mathrm{~g} / \mathrm{d})$ & 1 & & 1 & & 1 & & 1 & & 1 & & 1 & \\
\hline Fourth quarter $(118.57-145.84 \mathrm{~g} / \mathrm{d})$ & 1.04 & $0.85,1.27$ & 1.03 & $0.84,1.27$ & $1 \cdot 10$ & $0.85,1.41$ & 1.06 & $0.82,1.37$ & 0.89 & $0.70,1.12$ & 0.80 & $0.63,1.03$ \\
\hline \multicolumn{13}{|l|}{ Trans-fatty acids } \\
\hline First quarter $(<3.10 \mathrm{~g} / \mathrm{d})$ & 0.95 & $0.78,1 \cdot 16$ & 0.84 & $0.68,1.04$ & 1.00 & $0.77,1.30$ & 0.95 & $0.72,1.25$ & 0.96 & $0.76,1.21$ & 1.03 & $0.80,1.31$ \\
\hline Second and third quarters $(3.10-4.18 \mathrm{~g} / \mathrm{d})$ & 1 & & 1 & & 1 & & 1 & & 1 & & 1 & \\
\hline Fourth quarter $(4.19-7.73 \mathrm{~g} / \mathrm{d})$ & $0.78^{\star}$ & $0.62,0.99$ & 1.08 & $0.88,1.33$ & $1 \cdot 17$ & $0.91,1.49$ & $1 \cdot 14$ & $0.89,1.46$ & 0.85 & $0.67,1.07$ & 0.83 & $0.64,1.06$ \\
\hline \multicolumn{13}{|l|}{ MUFA } \\
\hline First quarter $(<78.05 \mathrm{~g} / \mathrm{d})$ & 0.94 & $0.77,1.15$ & 0.90 & $0.73,1.11$ & 0.89 & $0.68,1.15$ & 0.89 & $0.68,1.17$ & 0.94 & $0.74,1.18$ & 0.98 & $0.77,1.25$ \\
\hline Second and third quarters $(78.05-93.52 \mathrm{~g} / \mathrm{d})$ & 1 & & 1 & & 1 & & 1 & & 1 & & 1 & \\
\hline Fourth quarter $(93.53-104.16 \mathrm{~g} / \mathrm{d})$ & 0.98 & $0.81,1 \cdot 20$ & 0.98 & $0.80,1.21$ & 0.95 & $0.74,1.22$ & 0.96 & $0.74,1.24$ & 1.02 & $0.81,1.29$ & 1.08 & $0.85,1.38$ \\
\hline \multicolumn{13}{|l|}{ PUFA } \\
\hline First quarter $(<22.90 \mathrm{~g} / \mathrm{d})$ & 1.02 & $0.83,1.25$ & 0.94 & $0.76,1.17$ & 0.90 & $0.70,1.16$ & 0.82 & $0.63,1.07$ & 0.93 & $0.74,1.17$ & 0.94 & $0.73,1.21$ \\
\hline Second and third quarters $(22.90-32.46 \mathrm{~g} / \mathrm{d})$ & 1 & & 1 & & 1 & & 1 & & 1 & & 1 & \\
\hline Fourth quarter $(32.47-59.37 \mathrm{~g} / \mathrm{d})$ & 1.00 & $0.82,1.22$ & 1.03 & $0.83,1.27$ & $0.75^{*}$ & $0.57,0.97$ & $0.73^{*}$ & $0.55,0.96$ & 1.01 & $0.80,1.28$ & 1.08 & $0.84,1.40$ \\
\hline \multicolumn{13}{|l|}{ Ratio of $n-6$ to $n-3$ PUFA } \\
\hline First quarter & 0.97 & $0.80,1 \cdot 19$ & 0.99 & $0.80,1 \cdot 22$ & 1.08 & $0.84,1.40$ & 1.09 & $0.84,1.43$ & 0.90 & $0.71,1.13$ & 0.85 & $0 \cdot 66,1 \cdot 10$ \\
\hline Second and third quarters & 1 & & 1 & & 1 & & 1 & & 1 & & 1 & \\
\hline Fourth quarter & 0.94 & $0.77,1.15$ & 1.01 & $0.82,1.24$ & $1 \cdot 28^{*}$ & $1.00,1.64$ & $1.35^{*}$ & $1.05,1.73$ & $1 \cdot 14$ & $0.90,1.43$ & 1.09 & $0.85,1.40$ \\
\hline \multicolumn{13}{|l|}{$n-6$ PUFA } \\
\hline First quarter $(<19.32 \mathrm{~g} / \mathrm{d})$ & 1.03 & $0.85,1.26$ & 0.97 & $0.78,1.20$ & 0.92 & $0.71,1 \cdot 18$ & 0.85 & $0.66,1 \cdot 11$ & 1.01 & $0.80,1.27$ & 1.01 & $0.79,1.30$ \\
\hline Second and third quarters $(19.32-24.50 \mathrm{~g} / \mathrm{d})$ & 1 & & 1 & & 1 & & 1 & & 1 & & 1 & \\
\hline Fourth quarter $(24.51-49.23 \mathrm{~g} / \mathrm{d})$ & $1 \cdot 10$ & $0.90,1.35$ & $1 \cdot 15$ & $0.93,1.43$ & 0.86 & $0.66,1.12$ & 0.84 & $0.64,1.11$ & $1 \cdot 15$ & $0.92-1.45$ & 1.21 & $0.94-1.55$ \\
\hline \multicolumn{13}{|l|}{ Linoleic fatty acid } \\
\hline First quarter $(<18.64 \mathrm{~g} / \mathrm{d})$ & 1.05 & $0.86,1.28$ & 0.98 & $0.79,1.21$ & 0.93 & $0.72,1.19$ & 0.86 & $0.66,1.12$ & 1.00 & $0.80,1.26$ & 1.01 & $0.79,1.30$ \\
\hline Second and third quarters $(18.64-23.87 \mathrm{~g} / \mathrm{d})$ & 1 & & 1 & & 1 & & 1 & & 1 & & 1 & \\
\hline Fourth quarter $(23.87-47.75 \mathrm{~g} / \mathrm{d})$ & $1 \cdot 14$ & $0.93,1.39$ & 1.17 & $0.95,1.45$ & 0.85 & $0.65,1 \cdot 10$ & 0.83 & $0.63,1.09$ & $1 \cdot 14$ & $0.91,1.44$ & $1 \cdot 20$ & $0.94,1.53$ \\
\hline Linoleic fatty acid, conjugated & & & & & & & & & & & & \\
\hline First quarter $(<0.38 \mathrm{~g} / \mathrm{d})$ & 0.96 & $0.79,1.18$ & 0.93 & $0.75,1.15$ & 0.98 & $0.76,1.27$ & 0.98 & $0.75,1.27$ & 1.09 & $0.87,1.38$ & $1 \cdot 19$ & $0.93,1.52$ \\
\hline Second and third quarters $(0.38-0.54 \mathrm{~g} / \mathrm{d})$ & 1 & & 1 & & 1 & & 1 & & 1 & & 1 & \\
\hline Fourth quarter $(0.54-0.75 \mathrm{~g} / \mathrm{d})$ & 1.01 & $0.83,1.23$ & 1.01 & $0.82,1.24$ & 0.99 & $0.77,1.27$ & 0.96 & $0.74,1.25$ & 0.93 & $0.73,1.18$ & 0.88 & $0.69,1 \cdot 14$ \\
\hline$\gamma$-Linolenic fatty acid & & & & & & & & & & & & \\
\hline First quarter $(<0.11 \mathrm{~g} / \mathrm{d})$ & 0.90 & $0.73,1 \cdot 10$ & 0.91 & $0.73,1.12$ & 1.01 & $0.78,1.30$ & 1.07 & $0.82,1.39$ & $1 \cdot 14$ & $0.91,1.44$ & 1.20 & $0.94,1.53$ \\
\hline Second and third quarters $(0.11-0.16 \mathrm{~g} / \mathrm{d})$ & 1 & & 1 & & 1 & & 1 & & 1 & & 1 & \\
\hline Fourth quarter $(0.16-0.98 \mathrm{~g} / \mathrm{d})$ & 1.05 & $0.86,1 \cdot 28$ & 1.05 & $0.86,1.30$ & 1.04 & $0.81,1.33$ & 1.08 & $0.83,1.39$ & 0.94 & $0.74,1 \cdot 19$ & 0.96 & $0.74,1.24$ \\
\hline Arachidonic fatty acid & & & & & & & & & & & & \\
\hline First quarter $(<0.14 \mathrm{~g} / \mathrm{d})$ & 1.03 & $0.85,1.27$ & 1.02 & $0.82,1.26$ & 0.82 & $0.63,1.07$ & 0.86 & $0.66,1 \cdot 14$ & 0.88 & $0.69,1.13$ & 0.95 & $0.73,1.23$ \\
\hline Second and third quarters $(0.14-0.20 \mathrm{~g} / \mathrm{d})$ & 1 & & 1 & & 1 & & 1 & & 1 & & 1 & \\
\hline Fourth quarter $(0.20-0.44 \mathrm{~g} / \mathrm{d})$ & 1.04 & $0.86,1 \cdot 27$ & 1.02 & $0.83,1.25$ & 1.04 & $0.81,1.32$ & 1.04 & $0.81,1.34$ & 0.85 & $0.68,1.06$ & 0.93 & $0.73,1.17$ \\
\hline$n-3$ PUFA & & & & & & & & & & & & \\
\hline First quarter $(<5.55 \mathrm{~g} / \mathrm{d})$ & 1.08 & $0.88,1.32$ & 1.03 & $0.84,1.27$ & 0.91 & $0.71,1 \cdot 17$ & 0.89 & $0.69,1.15$ & 0.89 & $0.71,1 \cdot 12$ & 0.98 & $0.77,1.25$ \\
\hline Second and third quarters $(5.55-7.34 \mathrm{~g} / \mathrm{d})$ & 1 & & 1 & & 1 & & 1 & & 1 & & 1 & \\
\hline
\end{tabular}




\begin{tabular}{|c|c|c|c|c|c|c|c|c|c|c|c|c|}
\hline \multirow[b]{3}{*}{ Fatty acids } & \multicolumn{4}{|c|}{ Atopic eczema } & \multicolumn{4}{|c|}{ Allergic rhinitis } & \multicolumn{4}{|c|}{ Wheeze } \\
\hline & \multicolumn{2}{|c|}{ Unadjusted } & \multicolumn{2}{|c|}{ Adjusted model I† } & \multicolumn{2}{|c|}{ Unadjusted } & \multicolumn{2}{|c|}{ Adjusted model I† } & \multicolumn{2}{|c|}{ Unadjusted } & \multicolumn{2}{|c|}{ Adjusted model I } \\
\hline & OR & $95 \% \mathrm{Cl}$ & OR & $95 \% \mathrm{Cl}$ & $\mathrm{HR}$ & $95 \% \mathrm{Cl}$ & $\mathrm{HR}$ & $95 \% \mathrm{Cl}$ & $\mathrm{HR}$ & $95 \% \mathrm{Cl}$ & $\mathrm{HR}$ & $95 \% \mathrm{Cl}$ \\
\hline $\begin{array}{l}\text { Fourth quarter }(7.35-11.28 \mathrm{~g} / \mathrm{d}) \\
n-3 \text { PUFA from fish } \neq\end{array}$ & 0.94 & $0.77,1 \cdot 15$ & 0.93 & $0.75,1 \cdot 14$ & 0.78 & $0.60,1.02$ & $0 \cdot 82$ & $0.63,1.08$ & 0.95 & $0.75,1 \cdot 21$ & $1 \cdot 11$ & $0.85,1.43$ \\
\hline First quarter $(<0.38 \mathrm{~g} / \mathrm{d})$ & $1 \cdot 16$ & $0.95,1.42$ & $1 \cdot 16$ & $0.93,1.43$ & 0.99 & $0.77,1.28$ & 0.99 & $0.76,1.28$ & 1.15 & $0.92,1.45$ & 1.08 & $0.85,1.38$ \\
\hline Second and third quarters $(0.38-0.98 \mathrm{~g} / \mathrm{d})$ & 1 & & 1 & & 1 & & 1 & & 1 & & 1 & \\
\hline $\begin{array}{l}\text { Fourth quarter }(0.99-5.50 \mathrm{~g} / \mathrm{d}) \\
n-3 \text { PUFA from plants }\end{array}$ & 0.96 & $0 \cdot 79,1 \cdot 18$ & 0.97 & $0.79,1.20$ & 0.91 & $0.71,1 \cdot 17$ & 0.94 & $0.72,1.22$ & 0.95 & $0.75,1.20$ & 0.95 & $0.74,1.22$ \\
\hline First quarter $(<4.79 \mathrm{~g} / \mathrm{d})$ & 1.02 & $0 \cdot 83,1 \cdot 24$ & 0.97 & $0.78,1.19$ & 1.02 & $0.80,1.30$ & 0.97 & $0.75,1.25$ & 0.86 & $0.69,1.08$ & 0.94 & $0.74,1 \cdot 19$ \\
\hline Second and third quarters $(4.79-6.27 \mathrm{~g} / \mathrm{d})$ & 1 & & 1 & & 1 & & 1 & & 1 & & 1 & \\
\hline $\begin{array}{l}\text { Fourth quarter }(6 \cdot 28-8.97 \mathrm{~g} / \mathrm{d}) \\
\alpha \text {-Linolenic fatty acid }\end{array}$ & 0.93 & $0 \cdot 76,1 \cdot 14$ & 0.92 & $0 \cdot 74,1 \cdot 14$ & $0 \cdot 80$ & $0.61,1.04$ & 0.79 & $0.60,1.05$ & 0.88 & $0.69,1 \cdot 11$ & 0.94 & $0.73,1.21$ \\
\hline $\begin{array}{l}\alpha \text {-Linolenic fatty acid } \\
\text { First quarter }(<4.45 \mathrm{~g} / \mathrm{d})\end{array}$ & & & & & & & & & & & & \\
\hline $\begin{array}{l}\text { First quarter }(<4.45 \mathrm{~g} / \mathrm{d}) \\
\text { Second and third quarters }(4.45-6.40 \mathrm{~g} / \mathrm{d})\end{array}$ & $\begin{array}{l}1 \cdot 08 \\
1\end{array}$ & $0.89,1.32$ & $\begin{array}{l}1.05 \\
1\end{array}$ & $0.86,1.30$ & $\begin{array}{l}1.06 \\
1\end{array}$ & $0.83,1.35$ & $\begin{array}{l}1 \cdot 01 \\
1\end{array}$ & $0.79,1.29$ & $\begin{array}{l}0.79 \\
1\end{array}$ & $0.63,0.99$ & $\begin{array}{l}0.87 \\
1\end{array}$ & $0.69,1 \cdot 11$ \\
\hline Fourth quarter $(6.40-8.90 \mathrm{~g} / \mathrm{d})$ & 1.01 & $0.83,1 \cdot 23$ & 0.99 & $0.80,1.23$ & $0.74^{*}$ & $0.56,0.97$ & $0.74^{*}$ & $0.56,0.99$ & 0.87 & $0.69,1 \cdot 10$ & 0.95 & $0.74,1.22$ \\
\hline EPA & & & & & & & & & & & & \\
\hline $\begin{array}{l}\text { First quarter }(<0.07 \mathrm{~g} / \mathrm{d}) \\
\text { Second and third quarters }(0.07-0.23 \mathrm{~g} / \mathrm{d})\end{array}$ & 1.09 & $0.89,1.34$ & 1.07 & $0.86,1.33$ & $1 \cdot 02$ & $0.79,1.32$ & 0.99 & $0.76,1 \cdot 29$ & 1.05 & $0.83,1.32$ & 1.01 & $0.79,1.29$ \\
\hline $\begin{array}{l}\text { Second and third quarters }(0.07-0.23 \mathrm{~g} / \mathrm{d}) \\
\text { Fourth quarter }(0.23-1.25 \mathrm{~g} / \mathrm{d})\end{array}$ & 0.96 & $0.78,1 \cdot 17$ & 0.94 & $0.76,1.16$ & 1.00 & $0.78,1.29$ & 0.99 & $0.76,1.28$ & 0.97 & $0.77,1.23$ & $\begin{array}{l}1 \\
0.98\end{array}$ & $0.76,1.26$ \\
\hline DHA & & & & & & & & & & & & \\
\hline First quarter $(<0.19 \mathrm{~g} / \mathrm{d})$ & $1 \cdot 21$ & $0.99,1.48$ & $1 \cdot 18$ & $0.95,1.46$ & 1.00 & $0.78,1.29$ & 0.94 & $0.72,1.22$ & $1 \cdot 10$ & $0.87,1.38$ & 1.06 & $0.83,1.36$ \\
\hline $\begin{array}{l}\text { Second and third quarters }(0.19-0.60 \mathrm{~g} / \mathrm{d}) \\
\text { Fourth quarter }(0.60-3.5 \mathrm{~g} / \mathrm{d})\end{array}$ & $\begin{array}{l}1 \\
0.98\end{array}$ & $0.81,1.20$ & $\begin{array}{l}1 \\
0.98\end{array}$ & $0.79,1.20$ & $\begin{array}{l}1 \\
0.94\end{array}$ & $0.73,1.21$ & $\begin{array}{l}1 \\
0.93\end{array}$ & $0.72,1.21$ & $\begin{array}{l}1 \\
0.94\end{array}$ & $0.74,1.19$ & $\begin{array}{l}1 \\
0.93\end{array}$ & $0.73,1.20$ \\
\hline
\end{tabular}

${ }^{*} P<0.05$.

†Adjusted for sex of child, hospital of birth, duration of gestation, maternal age at delivery, maternal basic education, maternal smoking during pregnancy, mode of delivery, number of siblings at the time of the child's birth,

parental asthma, parental allergic rhinitis, pets at home by 1 year of age.
$\neq n-3$ PUFA from fish is a summary variable including all $n-3$ fatty acids from fish and fish products. 
Table 5. Association between maternal fatty acid intake during pregnancy and prevalence of atopic eczema and incidence of allergic rhinitis and wheeze in 5-year-old children

(Hazard ratios (HR), odds ratios and 95\% confidence intervals)

\begin{tabular}{|c|c|c|c|c|c|c|}
\hline & \multirow{2}{*}{\multicolumn{2}{|c|}{$\frac{\text { Atopic eczema }}{\text { Adjusted model II† }}$}} & \multirow{2}{*}{\multicolumn{2}{|c|}{$\begin{array}{c}\text { Allergic rhinitis } \\
\text { Adjusted model II } †\end{array}$}} & \multicolumn{2}{|c|}{ Wheeze } \\
\hline & & & & & \multicolumn{2}{|c|}{ Adjusted model II $†$} \\
\hline & OR & $95 \% \mathrm{Cl}$ & HR & $95 \% \mathrm{Cl}$ & OR & $95 \% \mathrm{Cl}$ \\
\hline \multicolumn{7}{|l|}{ Total fatty acids } \\
\hline First quarter $(<196.85 \mathrm{~g} / \mathrm{d})$ & 0.84 & $0.67,1.05$ & 0.94 & $0.71,1.24$ & 1.09 & $0.84,1.41$ \\
\hline Second and third quarters $(196.85-280.83 \mathrm{~g} / \mathrm{d})$ & 1 & & 1 & & 1 & \\
\hline Fourth quarter $(280.84-299.25 \mathrm{~g} / \mathrm{d})$ & 1.03 & $0.83,1.28$ & 0.96 & $0.73,1.25$ & 0.93 & $0.72,1.19$ \\
\hline \multicolumn{7}{|l|}{ SFA } \\
\hline First quarter $(<82 \cdot 24 \mathrm{~g} / \mathrm{d})$ & 1.00 & $0.80,1.24$ & 1.08 & $0.83,1.41$ & 1.0 & $0.78,1.29$ \\
\hline Second and third quarters $(82.24-118.56 \mathrm{~g} / \mathrm{d})$ & 1 & & 1 & & 1 & \\
\hline Fourth quarter $(118.57-145.84 \mathrm{~g} / \mathrm{d})$ & $1 \cdot 0$ & $0.81,1.24$ & 1.00 & $0.76,1.31$ & 0.77 & $0.59,1.00$ \\
\hline \multicolumn{7}{|l|}{ Trans-fatty acids } \\
\hline First quarter $(<3.10 \mathrm{~g} / \mathrm{d})$ & 0.84 & $0.68,1.05$ & 0.98 & $0.74,1.29$ & 1.08 & $0.84,1.40$ \\
\hline Second and third quarters $(3 \cdot 10-4.18 \mathrm{~g} / \mathrm{d})$ & 1 & & 1 & & 1 & \\
\hline Fourth quarter $(4.19-7.73 \mathrm{~g} / \mathrm{d})$ & 1.07 & $0.87,1.32$ & 1.09 & $0.85,1.41$ & 0.80 & $0.62,1.03$ \\
\hline \multicolumn{7}{|l|}{ MUFA } \\
\hline First quarter $(<78.05 \mathrm{~g} / \mathrm{d})$ & 0.90 & $0.72,1.12$ & 0.90 & $0.68,1.19$ & 1.02 & $0.79,1.32$ \\
\hline Second and third quarters $(78.05-93.52 \mathrm{~g} / \mathrm{d})$ & 1 & & 1 & & 1 & \\
\hline Fourth quarter $(93.53-104.16 \mathrm{~g} / \mathrm{d})$ & 0.98 & $0.79,1.23$ & 0.97 & $0.73,1.27$ & 1.08 & $0.83,1.40$ \\
\hline \multicolumn{7}{|l|}{ PUFA } \\
\hline First quarter $(<22.90 \mathrm{~g} / \mathrm{d})$ & 0.92 & $0.73,1.16$ & 0.81 & $0.61,1.07$ & 0.92 & $0.70,1.21$ \\
\hline Second and third quarters $(22.90-32.46 \mathrm{~g} / \mathrm{d})$ & 1 & & 1 & & 1 & \\
\hline Fourth quarter $(32.47-59.37 \mathrm{~g} / \mathrm{d})$ & 1.03 & $0.81,1.31$ & $0.71^{*}$ & $0.52,0.96$ & 1.09 & $0.82,1.44$ \\
\hline \multicolumn{7}{|l|}{ Ratio of $n-6$ to $n-3$ PUFA } \\
\hline First quarter & 1.00 & $0.80,1.23$ & $1 \cdot 10$ & $0.84,1.44$ & 0.86 & $0.66,1.11$ \\
\hline Second and third quarters & 1 & & 1 & & 1 & \\
\hline Fourth quarter & 1.01 & $0.82,1.25$ & $1.37^{*}$ & $1.07,1.77$ & 1.08 & $0.84,1.38$ \\
\hline \multicolumn{7}{|l|}{$n-6$ PUFA } \\
\hline First quarter $(<19.32 \mathrm{~g} / \mathrm{d})$ & 0.92 & $0 \cdot 74,1 \cdot 16$ & 0.82 & $0.62,1 \cdot 10$ & 1.0 & $0.76,1.32$ \\
\hline Second and third quarters $(19.32-24.50 \mathrm{~g} / \mathrm{d})$ & 1 & & 1 & & 1 & \\
\hline Fourth quarter $(24.51-49.23 \mathrm{~g} / \mathrm{d})$ & $1 \cdot 19$ & $0.94,1.50$ & 0.83 & $0.62,1 \cdot 12$ & $1 \cdot 17$ & $0.90,1.54$ \\
\hline \multicolumn{7}{|l|}{ Linoleic fatty acid } \\
\hline First quarter $(<18.64 \mathrm{~g} / \mathrm{d})$ & 0.94 & $0.75,1.18$ & 0.85 & $0.64,1 \cdot 12$ & 1.0 & $0.76,1.32$ \\
\hline Second and third quarters $(18.64-23.87 \mathrm{~g} / \mathrm{d})$ & 1 & & 1 & & 1 & \\
\hline Fourth quarter $(23.87-47.75 \mathrm{~g} / \mathrm{d})$ & 1.21 & $0.96,1.52$ & 0.81 & $0.60,1.09$ & $1 \cdot 15$ & $0.88,1.51$ \\
\hline Linoleic fatty acid, conjugated & & & & & & \\
\hline First quarter $(<0.38 \mathrm{~g} / \mathrm{d})$ & 0.94 & $0.76,1.16$ & 1.00 & $0.77,1.30$ & 1.24 & $0.97,1.59$ \\
\hline Second and third quarters $(0.38-0.54 \mathrm{~g} / \mathrm{d})$ & 1 & & 1 & & 1 & \\
\hline Fourth quarter $(0.54-0.75 \mathrm{~g} / \mathrm{d})$ & 0.99 & $0 \cdot 79,1 \cdot 22$ & 0.91 & $0.70,1.19$ & 0.84 & $0.65,1.10$ \\
\hline$\gamma$-Linolenic fatty acid & & & & & & \\
\hline First quarter $(<0.11 \mathrm{~g} / \mathrm{d})$ & 0.91 & $0.73,1.12$ & 1.06 & $0.82,1.38$ & 1.22 & $0.95,1.56$ \\
\hline Second and third quarters $(0.11-0.16 \mathrm{~g} / \mathrm{d})$ & 1 & & 1 & & 1 & \\
\hline Fourth quarter $(0.16-0.98 \mathrm{~g} / \mathrm{d})$ & 1.04 & $0.84,1.28$ & 1.04 & $0.80,1.35$ & 0.97 & $0.74,1.27$ \\
\hline Arachidonic fatty acid & & & & & & \\
\hline First quarter $(<0.14 \mathrm{~g} / \mathrm{d})$ & 0.98 & $0.78,1.23$ & 0.80 & $0.60,1.07$ & 0.98 & $0.74,1.31$ \\
\hline Second and third quarters $(0.14-0.20 \mathrm{~g} / \mathrm{d})$ & 1 & & 1 & & 1 & \\
\hline Fourth quarter $(0.20-0.44 \mathrm{~g} / \mathrm{d})$ & 1.06 & $0.85,1.33$ & $1 \cdot 13$ & $0.86,1.48$ & 0.87 & $0.68,1.11$ \\
\hline$n-3$ PUFA & & & & & & \\
\hline First quarter $(<5.55 \mathrm{~g} / \mathrm{d})$ & 1.03 & $0.82,1.28$ & 0.84 & $0.64,1 \cdot 10$ & 0.97 & $0.75,1.25$ \\
\hline Second and third quarters $(5.55-7.34 \mathrm{~g} / \mathrm{d})$ & 1 & & 1 & & 1 & \\
\hline Fourth quarter $(7.35-11.28 \mathrm{~g} / \mathrm{d})$ & 0.91 & $0.73,1.14$ & 0.85 & $0.64,1.14$ & $1 \cdot 14$ & $0.87,1.49$ \\
\hline$n-3$ PUFA from fish $\ddagger$ & & & & & & \\
\hline First quarter $(<0.38 \mathrm{~g} / \mathrm{d})$ & $1 \cdot 13$ & $0.90,1.42$ & 0.91 & $0.69,1.20$ & 1.08 & $0.84,1.39$ \\
\hline Second and third quarters $(0.38-0.98 \mathrm{~g} / \mathrm{d})$ & 1 & & 1 & & 1 & \\
\hline Fourth quarter $(0.99-5.50 \mathrm{~g} / \mathrm{d})$ & 1.00 & $0.80,1.26$ & 1.05 & $0.80,1.40$ & 0.97 & $0.73,1.28$ \\
\hline$n-3$ PUFA from plants & & & & & & \\
\hline First quarter $(<4.79 \mathrm{~g} / \mathrm{d})$ & 0.96 & $0.77,1.19$ & 0.95 & $0.73,1.24$ & 0.95 & $0.74,1.22$ \\
\hline Second and third quarters $(4.79-6.27 \mathrm{~g} / \mathrm{d})$ & 1 & & 1 & & 1 & \\
\hline Fourth quarter $(6.28-8.97 \mathrm{~g} / \mathrm{d})$ & 0.90 & $0.72,1.12$ & 0.78 & $0.58,1.04$ & 0.93 & $0.72,1.21$ \\
\hline$\alpha$-Linolenic fatty acid & & & & & & \\
\hline First quarter $(<4.45 \mathrm{~g} / \mathrm{d})$ & 1.05 & $0.85,1.30$ & 1.01 & $0.78,1.30$ & 0.87 & $0.67,1.12$ \\
\hline Second and third quarters $(4.45-6.40 \mathrm{~g} / \mathrm{d})$ & 1 & & 1 & & 1 & \\
\hline Fourth quarter $(6.40-8.90 \mathrm{~g} / \mathrm{d})$ & 0.98 & $0.78,1.22$ & $0.73^{*}$ & $0.54,0.98$ & 0.95 & $0.73,1.23$ \\
\hline EPA & & & & & & \\
\hline First quarter $(<0.07 \mathrm{~g} / \mathrm{d})$ & 1.04 & $0.83,1.31$ & 0.90 & $0.68,1.19$ & $1 \cdot 0$ & $0.77,1.29$ \\
\hline Second and third quarters $(0.07-0.23 \mathrm{~g} / \mathrm{d})$ & 1 & & 1 & & 1 & \\
\hline Fourth quarter $(0.23-1.25 \mathrm{~g} / \mathrm{d})$ & 0.97 & $0.77,1.22$ & 1.12 & $0.84,1.48$ & 1.03 & $0.78,1.36$ \\
\hline
\end{tabular}


Table 5. Continued

\begin{tabular}{|c|c|c|c|c|c|c|}
\hline & \multicolumn{2}{|c|}{ Atopic eczema } & \multicolumn{2}{|c|}{ Allergic rhinitis } & \multicolumn{2}{|c|}{ Wheeze } \\
\hline & \multicolumn{2}{|c|}{ Adjusted model II $†$} & \multicolumn{2}{|c|}{ Adjusted model II $†$} & \multicolumn{2}{|c|}{ Adjusted model II $†$} \\
\hline & OR & $95 \% \mathrm{Cl}$ & $\mathrm{HR}$ & $95 \% \mathrm{Cl}$ & OR & $95 \% \mathrm{Cl}$ \\
\hline \multicolumn{7}{|l|}{ DHA } \\
\hline First quarter $(<0.19 \mathrm{~g} / \mathrm{d})$ & $1 \cdot 15$ & $0.92,1.45$ & 0.85 & $0.64,1 \cdot 12$ & 1.04 & $0.80,1.34$ \\
\hline Second and third quarters $(0.19-0.60 \mathrm{~g} / \mathrm{d})$ & 1 & & 1 & & 1 & \\
\hline Fourth quarter $(0.60-3.5 \mathrm{~g} / \mathrm{d})$ & 1.00 & $0.80,1.26$ & 1.05 & $0.79,1.39$ & 0.95 & $0.72,1.26$ \\
\hline
\end{tabular}

* $P<0.05$.

$\dagger$ In addition to the covariates in model I, adjusted for energy-adjusted maternal intake of vitamin $C, Z n$, Se, vitamin D and vitamin E. $\ddagger n$-3 PUFA from fish is a summary variable including all $n-3$ fatty acids from fish and fish products.

actual allergic manifestations. The role of supplementation with $n-3$ and $n-6$ PUFA for primary prevention of allergic outcomes has provided inconclusive evidence ${ }^{(33-37)}$.

Recently, it has been suggested that the ratio of $n-6: n-3$ FA, rather than the intake of their absolute amount, may represent a more important indicator of optimum health ${ }^{(38,39)}$. Although previous studies have been inconsistent ${ }^{(4,39)}$, the results from the present study, however, show that a higher ratio of $n-6: n-3$ FA was associated with an increased risk of rhinitis in the offspring by the age of 5 years. While this finding is in line with the results of an Australian study reporting an enhanced risk of asthma in children aged 8 years with a higher ratio of $n-6: n-3$ FA during pregnancy ${ }^{(39)}$, it is at odds with that of a recent Japanese study reporting no association $^{(32)}$. In a previous US cohort, cord blood ratios of AA:EPA and linoleic acid: $\alpha$-linolenic acid were positively associated with eczema and wheeze, respectively, while the ratio of $\alpha$-linolenic acid: $n$-3 PUFA was inversely associated with wheeze in 30- to 42-month-old toddlers ${ }^{(40)}$. In another US study, higher n-3 EPA, n-6 AA and a reduced ratio of AA:EPA were associated with reduced allergen-stimulated interferon- $\boldsymbol{\gamma}$ levels in neonates ${ }^{(41)}$.

We found an increased risk of rhinitis with high maternal consumption of butter. It has been hypothesised that margarines may increase the risk of allergies, whereas butter may decrease the risk $^{(2)}$. The present results of no association between consumption of margarines and the risks of allergies did not support this proposition. In addition, our data on butter are in contrast to the hypothesised role of butter in the development of allergies, and also contradictory to the present observation on the effect of the ratio of $n-6: n-3$ FA on the risk of rhinitis, considering that $n-6$ FA are particularly derived from margarines. We lack the explanation for these disparities, but as earlier noted, it may highlight the complex mechanisms relating FA to the development of allergies, especially during early life. In a German cohort, maternal consumption of margarine but not butter during pregnancy was associated with an increased risk of allergies in the offspring $^{(42)}$, whereas an Italian retrospective cohort study found no association between either maternal consumption of butter or margarine and atopy in the offspring ${ }^{(6)}$. Oily fish is a major source of $n-3$ PUFA, and its consumption during pregnancy has been related to a reduced risk of asthma ${ }^{(7)}$, eczema ${ }^{(9,10)}$, house dust mite, wheeze ${ }^{(9)}$ and allergic sensitisation $^{(6,8)}$ in the offspring. In contrast, in an 8 -year longitudinal follow-up study from The Netherlands, maternal fish consumption during pregnancy was not associated with asthma or any asthma symptom in the offspring ${ }^{(11)}$. We did not have a measure of oily fish in the present study; therefore, we were unable to assess its association with the endpoints.

\section{Conclusion}

The present data indicate that maternal consumption of butter, the ratio of $n-6: n-3$ PUFA, and intake of PUFA and $\alpha$-linolenic during pregnancy may be potential determinants of the development of allergic rhinitis in the offspring. In the light of discordant reports, more evidence is needed to confirm and further define the putative role of dietary butter and FA in the current increasing prevalence of allergic diseases.

\section{Acknowledgements}

This study was supported by the following: the Academy of Finland (grants 44105, 48724, 80846, 201988, 126813, 129492); the Finnish Pediatric Research Foundation; Doctoral Programs in Public Health; the Juho Vainio Foundation; the Yrjö Jahnsson Foundation; Medical Research Funds, Turku; Oulu and Tampere University Hospitals; Juvenile Diabetes Research Foundation; Novo Nordisk Foundation; the University of Tampere Foundation; and EU Biomed 2 Program (BMH4-CT98-3314). The authors are grateful to the DIPP doctors, research nurses, nutritionists and laboratory staff for their continuous collaboration through the years. The authors also express their gratitude to Sirpa Pohjola and Ilona Kalliomäki for their expert technical assistance. The authors declare that they have no financial relationship or conflict of interest related to this manuscript to disclose. The authors' contributions were as follows: B. I. N. and M. E. designed, analysed and prepared the present paper under the supervision of S. M. V. and M. K. S. M. V. designed and was responsible for the DIPP Nutrition and Allergy studies. S. M. V. and M. K. planned the allergy study questionnaire 
for 5-year-olds. M. L. participated in the data analysis, interpretation, preparation and review of the manuscript and revising it critically for important intellectual content. S. A. and C. K.-K. were responsible for the data acquisition and preparation, interpretation of the results and critically reviewing the manuscript. R. V., J. I., O. S. and M. K. were responsible for data collection in the clinics and for paediatric expertise in this study, and review of the manuscript and revising it critically for important intellectual content.

\section{References}

1. Devereux G (2006) The increase in the prevalence of asthma and allergy: food for thought. Nat Rev Immunol 6, 869-874.

2. Black PN \& Sharpe S (1997) Dietary fat and asthma: is there a connection? Eur Respir J 10, 6-12.

3. Prescott SL \& Calder PC (2004) n-3 Polyunsaturated fatty acids and allergic disease. Curr Opin Clin Nutr Metab Care $7,123-129$

4. Kompauer I, Demmelmair H, Koletzko B, et al. (2004) $n 6 / n 3$ Hypothesis and allergies: biologically plausible, but not confirmed. Eur J Med Res 9, 378-382.

5. Miyake Y, Sasaki S, Tanaka K, et al. (2009) Maternal fat consumption during pregnancy and risk of wheeze and eczema in Japanese infants aged 16-24 months: the Osaka Matenal and Child Health Study. Thorax 64, 815-821.

6. Calvani M, Alessandri C, Sopo SM, et al. (2006) Consumption of fish, butter and margarine during pregnancy and development of allergic sensitizations in the offspring: role of maternal atopy. Pediatr Allergy Immunol 17, 94-102.

7. Salam MT, Li YF, Langholz B, et al. (2005) Maternal fish consumption during pregnancy and risk of early childhood asthma. J Asthma 42, 513-518.

8. Fitzsimon N, Fallon U, O'Mahony D, et al. (2007) Mothers' dietary patterns during pregnancy and risk of asthma symptoms in children at 3 years. Ir Med J 100, 27-32.

9. Romieu I, Torrent M, Garcia-Esteban R, et al. (2007) Maternal fish intake during pregnancy and atopy and asthma in infancy. Clin Exp Allergy 37, 518-525.

10. Willers SM, Devereux G, Craig LC, et al. (2007) Maternal food consumption during pregnancy and asthma, respiratory and atopic symptoms in 5-year-old children. Thorax $\mathbf{6 2}$, $772-778$.

11. Willers SM, Wijga AH, Brunekreef B, et al. (2008) Maternal food consumption during pregnancy and the longitudinal development of childhood asthma. Am J Respir Crit Care Med 178, 124-131.

12. Kupila A, Muona P, Simell T, et al. (2001) Feasibility of genetic and immunological prediction of type I diabetes in a population-based birth cohort. Diabetologia $\mathbf{4 4}$, 290-297.

13. Virtanen SM, Kenward MG, Erkkola M, et al. (2006) Age at introduction of new foods and advanced beta cell autoimmunity in young children with HLA-conferred susceptibility to type 1 diabetes. Diabetologia 49, 1512-1521.

14. Erkkola M, Karppinen M, Javanainen J, et al. (2001) Validity and reproducibility of a food frequency questionnaire for pregnant Finnish women. Am J Epidemiol 154, 466-476.

15. Arkkola T, Uusitalo U, Pietikainen M, et al. (2006) Dietary intake and use of dietary supplements in relation to demographic variables among pregnant Finnish women. $\mathrm{Br}$ J Nutr 96, 913-920.

16. Asher MI, Keil U, Anderson HR, et al. (1995) International Study of Asthma and Allergies in Childhood (ISAAC): rationale and methods. Eur Respir J 8, 483-491.

17. Remes ST, Korppi M, Kajosaari M, et al. (1998) Prevalence of allergic rhinitis and atopic dermatitis among children in four regions of Finland. Allergy 53, 682-689.

18. Willet W (1998) Nutritional Epidemiology. New York, NY: Oxford University Press.

19. Masson LF, McNeil G, Tomany JO, et al. (2003) Statistical approaches for assessing the relative validity of a foodfrequency questionnaire: use of correlation coefficients and the kappa statistic. Public Health Nutr 6, 313-321.

20. King JC (2000) Physiology of pregnancy and nutrient metabolism. Am J Clin Nutr 71, 1218S-1225S.

21. Prasad M, Lumia M \& Erkkola M (2010) Diet composition of pregnant Finnish women: changes over time and across seasons. Public Health Nutr 13, 939-946.

22. Salvatore S, Keymolen K, Hauser B, et al. (2005) Intervention during pregnancy and allergic disease in the offspring. Pediatr Allergy Immunol 16, 558-566.

23. Sly PD (2011) The early origins of asthma: who is really at risk? Curr Opin Allergy Clin Immunol 11, 24-28.

24. Prahalad S (2000) Atopy, autoimmunity, and the $\mathrm{T}(\mathrm{H}) 1$ $\mathrm{T}(\mathrm{H}) 2$ balance. $J$ Pediatr 137, 446-449.

25. Stene LC \& Joner G (2004) Norwegian Childhood Diabetes Study Group. Atopic disorders and risk of childhoodonset type 1 diabetes in individuals. Clin Exp Allergy 34, 201-206.

26. Haahtela T, von Hertzen L, Mäkela M, et al. (2008) Finnish allergy programme 2008-2018-time to act and change the course. Allergy 63, 634-645.

27. Fritsche K (2006) Fatty acids as modulators of the immune response. Annu Rev Nutr 26, 45-73.

28. Dubnov-Raz G, Finkelstein Y \& Koren G (2007) Omega-3 fatty acid supplementation during pregnancy: for mother, baby, or neither? Can Fam Physician 53, 817-818.

29. Jensen CL (2006) Effects of $n-3$ fatty acids during pregnancy and lactation. Am J Clin Nutr 83, 1452S-1457S.

30. Prescott SL \& Dunstan JA (2007) Prenatal fatty acid status and immune development: the pathways and the evidence. Lipids 42, 801-810.

31. Nwaru BI, Ahonen S, Kaila M, et al. (2010) Maternal diet during pregnancy and allergic sensitization in the offspring by 5 years of age: a prospective cohort study. Pediatr Allergy Immunol 21, 29-37.

32. Saito K, Yokoyama T, Miyake Y, et al. (2010) Maternal meat and fat consumption during pregnancy and suspected atopic eczema in Japanese infants aged 3-4 months: the Osaka Maternal and Child Health Study. Pediatr Allergy Immunol 21, 38-46.

33. Dunstan JA, Mori TA, Barden A, et al. (2003) Maternal fish oil supplementation in pregnancy reduces interleukin-13 levels in cord blood of infants at high risk of atopy. Clin Exp Allergy 33, 442-448.

34. Dunstan JA, Mori TA, Barden A, et al. (2003) Fish oil supplementation in pregnancy modifies neonatal allergenspecific immune responses and clinical outcomes in infants at high risk of atopy: a randomized, controlled trial. J Allergy Clin Immunol 112, 1178-1184.

35. Marks GB, Mihrshahi S, Kemp AS, et al. (2006) Prevention of asthma during the first 5 years of life: a randomized controlled trial. J Allergy Clin Immunol 118, 53-61.

36. Almqvist C, Garden F, Xuan W, et al. (2007) Omega-3 and omega-6 fatty acid exposure from early life does not affect 
atopy and asthma at age 5 years. I Allergy Clin Immunol 119, $1438-1444$.

37. Anandan C, Nurmatov U \& Sheikh A (2009) Omega 3 and 6 oils for primary prevention of allergic disease: systematic review and meta-analysis. Allergy 64, 840-848.

38. Korotkova M, Telemo E, Yamashiro Y, et al. (2004) The ratio of $n-6$ to $n-3$ fatty acids in maternal diet influences the induction of neonatal immunological tolerance to ovalbumin. Clin Exp Immunol 137, 237-244.

39. Oddy WH, de Klerk NH, Kendall GE, et al. (2004) Ratio of omega- 6 to omega- 3 fatty acids and childhood asthma. J Asthma 41, 319-326.
40. Newson RB, Shaheen SO, Henderson AJ, et al. (2004) Umbilical cord and maternal blood red cell faty acids and early childhood wheezing and eczema. J Allergy Clin Immunol 114, 531-537.

41. Gold DR, Willweth BM, Tantisira KG, et al. (2006) Associations of cord blood fatty acids with lymphocyte proliferation, IL-13, and IFN- $\gamma$. J Allergy Clin Immunol 117, 931-938.

42. Sausenthaler S, Kompauer I, Borte M, et al. (2006) Margarine and butter consumption, eczema and allergic sensitization in children. The LISA birth cohort study. Pediatr Allergy Immunol 17, 85-96. 